\title{
Impact of Coastal Reclamation on Environmental Sustainability and Tourism-Based Economy on the North Coast of Java
}

\author{
Bambang Eko Turisno* and I Gusti Ayu Gangga Santi Dewi
}

\author{
Faculty of Law, Universitas Diponegoro, Semarang, Indonesia
}

\begin{abstract}
Coastal reclamation has been increasingly growing in Indonesia is done by multiplying natural resources and economy in coastal management for the welfare of the surrounding community. The research objective is to determine the potential of coastal reclamation land in Coastal residents that is sustainable and to reconstruct a just marine environment reclamation policy. This research can be broadly grouped into the realm of the socio-legal approach. The results of the research showed that the potential for marine reclamation on the north coast of Jawa for business development and tourism areas for the welfare of the surrounding community. Since 2014, the authority of the sea and the coast has become the authority of the provincial government. The authority and supervision of the regional government are reduced, considered detrimental for the life of the coastal community which is the majority of fishermen. Hence, the policy reconstruction of marine environment reclamation is carried out by reconstructing the value of policies in the form of making policies that genuinely involve community and reconstructing the laws and regulations that are still in force.
\end{abstract}

Keywords: Coastal reclamation, business, tourism development, marine environment, policy.

\section{INTRODUCTION}

In this globalization era, land needs in Indonesia are increasing both for residential needs and business activities (Firman, 2004; Tunas \& Peresthu, 2010). Increasing population and commercial purposes put pressure on the availability of land, especially in urban areas (Firman, 1997). The large demand for land areas has encouraged the state through the government to try to meet the needs of the land with one alternative, by the way, to change the coastal area into new land known as coastal reclamation activities (Arsyad, 2008). The development of new areas by reclaiming the coastal environment is mostly done in several big cities in Indonesia where the rate of population growth and business sectors requires a lot of lands that is so fast (Azwar et al., 2013).

Coastal reclamation is an effort to utilize an area of land that is not useful and watery to be used as useful land by draining or stockpiling. The usual place for marine environment reclamation is the marine environment and/or coast and offshore. The 2007 Coastal Area Management Law explains that reclamation can only be carried out if the social and economic benefits obtained are greater than the social and economic costs. Coastal reclamation is a landfill activity by inserting several materials to the coastal area that is constantly inundated to obtain dry land on which buildings can be built as a joint effort in the public interest (Dewi, 2019). However, the

*Address correspondence to this author at the Faculty of Law, Universitas Diponegoro, Semarang, Jl. Prof. Soedarto, Tembalang, Semarang, Central Java 50275, Indonesia; Tel: +62-2476918201; Fax: +62-247691820;

E-mail: bambangturisno.undip@gmail.com implementation of the reclamation is also obliged to maintain and pay attention to several things in forms of sustainability between the interests of the utilization and livelihood of the community, the balance between the utilization and interests of the preservation of the coastal environment, and small islands, and the technical requirements of extraction, dredging, and material stockpile. The positive impact of coastal reclamation is an increase in the quality and economic value of the coastal area, reducing less productive land along the coast, protecting the coast from erosion, improving the condition of aquatic habitat, employment and others. Also, reclamation will also hurt socioeconomic changes such as difficulties in public access to the marine environment and reduced livelihoods (Huda, 2013). The marine environment reclamation process that has not been going well is feared to have negative impacts such as more material being washed away, causing siltation of waters, and if this continues it will threaten the coastal ecosystem (Djainal, 2012).

The development of new areas by reclaiming marine environment is mostly done in Indonesia, as well as in Kajen Regency, which has high population growth rates and complex business sectors that require land. From the environmental economy point of view regarding coastal reclamation, various potential natural and human resources for coastal management should be for the welfare of the surrounding community (Wong, 1998; Rasiah et al., 2018). From the coastal population's views, coastal reclaimed land should be utilized with various activities including business development of coastal fishermen and tourism (Tungka et al., 2012; Walyoto \& Peranginangin, 2018). Several 
studies have highlighted the relationship between political trends and increased coastal reclamation practices and environmental carrying capacity (Priyandes \& Majid, 2009; Marfai et al., 2008; Kusen, \& Tioho, 2009; Wisha et al., 2018), while other studies also analyze the relationship between economic management in coastal areas as a result of changes spatial planning in coastal areas (Yurnita et al., 2017; Kalalo, 2019). Hence, conducting research is very important and is a necessity to obtain a reconstruction of coastal reclamation policy as a useful and sustainable land area that is fair. Hence, the study aims to analyse the potential for coastal reclamation on tourism-based businesses and the policy and regulation for marine environment reclamation as tourism.

\section{METHOD}

This research belongs to the tradition of qualitative research. The use of qualitative methods is expected to find hidden meanings behind objects and subjects to be studied. The tradition of qualitative research is unknown to the population because of the nature of the case study research. Qualitative research has iterations of four elements of determining samples purposively, inductive analysis, grounded theory, and interim design according to the context (Muhardjir, 2002).

This study begins with secondary data as initial data then proceed with primary data or field data. This means that empirical legal research still rests on the normative premise, where the focus of the study is on the essence of the law contained in the form of norms both in the form of laws and regulations and in other forms of law such as the law that lives in the community, then linked to the reality in the field today. Samples that become informants are determined purposively (Soeratno \& Arsyad, 1993). This research can be broadly grouped into the realm of the sociolegal approach (Rahardjo, 2009). In this case, there are two aspects of research, in form of legal research aspects. Hence, the object of research remains in the form of law in the sense of norm and socio research, namely the use of methods and theories of social science theories of law to help researchers conduct analysis (Zamroni, 1992). This approach is used to understand the law in the context of the community. Tamanaha (2006) argues that between law and society has a frame called The Law-Society Framework which has certain relationship characteristics. This relationship is indicated by two basic components. The first component consists of two main themes namely the idea that states that law is a mirror of society and the idea that the function of law is to maintain social order. The second component consists of three elements, namely: custom/consent; morality/reason, and positive law.

This research is about the potential of equitable coastal environment reclamation policies that can potentially benefit all parties concerned. In this study, a reconstruction of social reality is carried out, by prioritizing the interaction between research and what is studied through sources and informants and paying attention to the context that shapes the input, process, and results of research, as well as its meanings. Coastal reclamation area which has been managed as a tourist area and part of the area as a marine product is a potential that is utilized by the surrounding community. The location of the study was carried out on the land reclaimed by the marine environment in Kajen Regency, Central Java Province by observing the condition of the management of the land reclaimed by the marine environment. The chosen research tradition is qualitative research so that the form of research data is not in the form of numbers for quantitative-statistical analysis, but the data is information in the form of words or called qualitative data (Alwasilah, 2002).

Data sources in this study are primary data sources extracted from informants, especially managers of coastal areas, village apparatus around the study site, employees of the National Land Agency, Office of Tourism and Culture, Office of Maritime Affairs and Fisheries, to find out its settings, actions, and policies. To find out the status of land rights and postreclamation maintenance, the efforts that have been made are also extracted from information at the marine environment reclamation location. While the secondary data in this study consisted of legal materials and secondary legal materials. Primary legal materials in this study include national law.

\section{BETWEEN ECONOMIC INTERESTS AND ENVIR- ONMENTAL SUSTAINABILITY IN RECLAMATION}

Land is a property that has a permanent nature because it provides benefits to be planned for various interests in the future. Article 33 (3) of the 1945 Constitution of the Republic of Indonesia regulates that the earth and water and the natural resources contained therein shall be controlled by the state and used for the greatest prosperity of the people. The 
state control means 'the right to control the state' which authorizes the state to regulate and carry out the designation, use, supply, and maintenance of earth, water, and space, determine and regulate legal relations between people and the earth, water, and space and determine and regulate legal relations between people and legal actions concerning the earth, water, and space (Harsono, 2002). The contents of Article 33 (3) of the 1945 Constitution contains a very basic constitutional mandate, namely that land must be used to realize people's welfare. The use of land that does not bring prosperity to the people is morally contrary to the 1945 Constitution of the Republic of Indonesia. Indonesian Land Law of 1960 asserted that land controlled by the state was referred to as state land. Reclamation Land is a state land regulated in a Circular of the State Minister for Agrarian Affairs/Head of the National Land Agency No: $410-1293$ concerning Ordering the Status of Embossed Land and Reclamation Land. Therefore, coastal reclamation is needed regulation in the form of social justice policies based on the Pancasila and the 1945 Constitution.

Current regulations on land in Indonesia and its authorization have placed environmental sustainability as a top priority and have included related fields such as forest environmental regulation, exploitation of natural resources and energy, and the marine environment (McCarthy \& Zen, 2010; Colchester et al., 2007; Contreras-Hermosilla et al., 2005; Azhar et al., 2018; Zerner, 1994). Therefore, environmental policy settings have a direct social and economic effect on people's livelihoods (Dutton, 2005). In a social context, the livelihoods of the people of coastal residents in Kajen are various, including civil servants, private employees, traders, and communities around the coast working as fishermen, fish farmers, and rice farmers. Residents on the northern coast of Kajen are known for their natural tourism and batik business so that many tourists come to enjoy the beauty of nature and buy batik. Every year on a certain date, the government and residents hold various events that attract tourists, including the Nusantara Batik Week (PBN) and the International Batik Week (PBI). Batik Nusantara Week is held once a year in October, while International Batik Week takes place every 3 years in the same month. Activities organized in this event are gala dinners, fashion shows, cultural titles, seminars, carnivals for batik fashion creations, exhibitions of batik products at home and abroad, great sales, and culinary tours.

The majority of residents people living on the coast live as fishermen. Social relations between the community members are well established between residents. This is marked by the togetherness that is intertwined in society, the bond of solidarity is established based on a sense of kinship and the same fate. Existing social institutions also run well, such as village gatherings, religious activities, and other social activities. Coastal communities, as is known, are generally quite close to poverty, this is due to economic and social factors so that they find it difficult to get an adequate education, eventually becoming one reason to choose to become a fisherman (Retnowati, 2011).

Before the marine environment reclamation with the creation of a giant retaining seawater embankment in early 2019 , the economic level of the community was very low due to flooding in Kajen. Coastal communities remain in the flooded area and have no desire to move to a more suitable location. Impacts caused by flooding include causing material losses for residents around the coast due to damage to buildings, causing the damaged environment to become dirty, causing illness for residents, especially children, disrupting traffic for city residents crossing the road for access to the life they are good for offices, markets and schools for children and the scarcity of clean water because water is polluted mixed with dirty water flooding.

The coastal area in Kajen faces floods almost every day. In Indonesia, flooding nowadays is frequently prevented by reclaiming the coastal area by making large embankment buildings to hold seawater into the mainland (Marfai \& King, 2008). Reclamation can be done using the physical treatment, namely by making coastal protective buildings in the form of embankments and floodgates equipped with water pumps. Flood Management in Coastal residents conducted by the Central Government and the Regional Government of Kajen Regency, among others by making a large dike breaking the waves by reclaiming the marine environment; pumping water entering the mainland into the sea; enlarging the capacity of existing rivers and drainage by periodically dredging; and urging the public not to throw garbage in the waters of the sea, rivers and settlement channels.

Physical development that has been carried out include wave-breaking embankment on the marine environment with a total length of $7.997 \mathrm{~km}$; long storage or sling channel parallel to the breakwater dike; pump house building to periodically dispose of water stored in long storage; building river embankments by raising the river parapet low. Coastal reclamation in addition to tackling floods in Kajen, land from 
reclamation is utilized by the regional government for the construction of various activities that are beneficial to the welfare of the communities around the coast.

\section{MARINE ENVIRONMENT RECLAMATION POLICY}

Based on the 2014 Local Government Law, the authority for coastal reclamation is the authority of the provincial government and all forms of licensing related to coastal reclamation are the provincial government. However, the Act is reaping a polemic. The law mandates maritime, coastal and small island affairs, in which 70 percent is taken over by the central government and the remain of 30 percent is taken over by the provincial regional government and without involving the district or city government. Though almost every region in Indonesia has the sea and serves to improve the welfare of the community and increase local income.

According to the Head of the Fisheries and Maritime Affairs Office of the Regency of Kajen that the marine and fisheries sector is very important and should be the authority of the regency or city government and licensing of the sector issued by the regency or city government according to applicable laws. Final report on a legal review of the division of central and regional authorities in marine management research and development center for the national legal system, (National Legal Development Agency of the Ministry of Law and Human Rights of the Republic of Indonesia, 2015) stated that the granting of authority only to the provincial government makes the government both the city and district areas do not care about the sea and coastal areas because the coastal sea area policy is outside their authority. Even though the one who knows directly the condition of the coastal sea area is the local government, not the provincial government. On the other hand, the unequal distribution of authority can reduce the regional budget, and also when there are problems in the regions related to various policies, the handling must all be done by the central government.

In the provisions of coastal reclamation authority governed by the Management of Coastal Areas and Small Islands in 2007, there are significant differences with the 2014 Regional Government Law. The 2007 Coastal and Small Islands Management Law give authority to the regional authorities (provinces and district/city) to take care of the coast and small islands comprehensively. Here the unclear division of authority between the provincial and district/city governments in managing coastal resources and small islands arises because the 2007 Coastal and Small Islands Management Act are still in force and there are no implementing regulations for the 2014 Regional Government Law related to the authority to manage coastal areas and small islands.

Although it has been specifically regulated in Regulation of the Minister of Maritime Affairs and Fisheries of the Republic of Indonesia Number 23/Permen-KP/2016 concerning Management of Coastal and Small Islands Management, the provisions relating to regional authority in the Management Act of Coastal and Small Islands in 2007 and Presidential Regulation No. 122 of 2012 is still valid and has not been revoked, this results in legal uncertainty in the community.

In the context of the impact of the marine environment of reclamation policy, the principle of a new regulation that defeats or paralyzes the old rule (lex posteriori derogat legi priori) applies, namely the 2014 Local Government Law and the Minister of Maritime Affairs and Fisheries Regulation No. 23 of 2016 amended the 2007 Coastal and Small Islands Management Law 2007 and Presidential Regulation No. 122 of 2012, whichever new regulation overcame or paralyzed the old regulation. It has been contradictory in the authority of environmental supervision which in the policy revokes the authority of the regional governments. Thus, after the enactment of the 2014 Local Government Law, there was a conflict of the authority of the district/city government towards the Management of Coastal Areas and Small Islands.

In consideration of the Minister of Maritime Affairs and Fisheries Regulation No. 23 of 2016 states that in the framework of implementing synergy between the Central Government and the regions, ministries/nonministerial government institutions, Minister of Maritime Affairs and Fisheries Regulation No. 34/2014 concerning Management Planning for Coastal Areas and Small Islands needs to adjust to Government Law Regions in 2014, as amended, were last amended by Law Number 9 of 2015 concerning the Second Amendment to Law Number 23 of 2014 concerning Regional Government. Based on the above explanation it can be said that the presence of the Minister of Maritime Affairs and Fisheries Regulation No. 23 of 2016 as a legal basis for the implementation of coastal reclamation is the authority of the provincial government, not the regional government. Although the provisions of the authority of local governments in the Law on the Management of Coastal Areas and Small 
Islands in 2007 and Presidential Regulation No. 122 of 2012 has not been revoked.

The provincial government obtained a large and broad authority from the 2014 Local Government Law and the Minister of Maritime Affairs and Fisheries Regulation No. 23 of 2016. The problem is, is the province able to carry out so many and wide-ranging regional tasks. The shifting of district authority in the management of coastal areas and small islands to the provincial government is a quite burdensome job for the provincial government and until now there has been no mandate from the province to the regional government particularly the Maritime and Fisheries Service.

Since the enactment of the 2014 Local Government Law, the Central Java Provincial Government had exercised authority in coastal reclamation by working with the district government, for example regarding making spatial planning which later became the basis for the regulation regional. Thus, there is no longer any difference between the zoning plans of the regional government and the provincial government in determining policies. The Central Java provincial government has coordinated with the city government by continuing what the city government has done about the management of coastal areas and small islands, then the results of the continued work are determined through the Central Java provincial regulations. and regional regulations in Kajen Regency.

\section{SOCIAL PARTICIPATION IN ENVIRONMEN- TALLY-ORIENTED ECONOMIC DEVELOPMENT}

The lack of grassroots participation in environmental economic policymaking makes the environmental problems faced at the local level more complex. This requires policies that accommodate the aspirations of local groups and policymakers at the local level to participate in environmental and economic policies (Wells \& McShane, 2004; Bäckstrand, 2003). For this reason, a reconstruction of equitable coastal reclamation policy related to the management of the reclaimed coastal land is needed to accommodate this. reconstruction of the value of the coastal reclamation policy in the form of partitioning and humanistic policymaking with genuine involvement of the community.

Reconstruction of coastal reclamation policy law, includes by considering the implementation of the 2014 Local Government Law and the 2016 Ministerial Regulation also the 2007 Coastal and Small Islands Management Act 2007 and Presidential Regulation
No.122 of 2012 must be consistent and comprehensive in the field for legal certainty in the management of coastal and island areas. -small island. Conflicts of authority must be revoked immediately by revising changes to the article. Coastal reclamation policy from the level of law to regional regulation which is oriented towards substantive justice with a progressive legal basis, based on Pancasila and the 1945 Constitution. There are clear rules regarding the marine environment and coastal supervision by the local area in cooperation with relevant agencies in the regions, provinces, and central government.

Mahfud (2010) stated that national law must be able to create social justice, in the sense that it must be able to shorten the gap between the strong and the weak and provide special protection against the weak. Without special protection from the law, the weak group will always lose if they are released to compete or fight freely with the strong group. The Indonesian rule of law should be a state that makes its people happy and for this reason, the concept of progressive justice is chosen, which is none other than substantive justice (Rahardjo, 2006). Efforts to realize this substantive justice, because in practice only procedural justice is met due to the use of procedural justice positivism paradigm.

In the context of this research, the reconstruction of coastal reclamation policy that needs to be done is to create a new consideration of marine environment reclamation policy based on the value of justice. The next step is to analyze synchronization, consistency, and harmonization with the wishes of the constitution and Pancasila which aim to build a socially just marine environment reclamation policy. After this stage is passed, the next stage is to revise or revoke the legislation product related to coastal reclamation that is contrary to the wishes of the constitution and reorganize the building of the legal system regarding national marine environment reclamation policies based on the fair value of Pancasila (Gangga Santi Dewi, 2019).

As for environmental economic considerations, coastal reclamation has some benefits. The coastal reclamation was able to increase the development of mangrove cultivation. Mangrove cultivation is gradually made on the reclaimed land, by planting several types of mangrove plant collections. This benefit was long obtained by neighboring countries in ASEAN, such as Malaysia and Singapore, and Thailand (Jusoff, 2013; Fortes, 1991; Flaherty \& Karnjanakesorn, 1995). The 
land will be filled with various integrated fisheries, marine, and forestry activities such as seaweed cultivation and mangrove crab cultivation. The benefits for coastal reclamation is in addition to development for educational activities and others around the reclamation area, a business is being planted with mangroves as a livelihood for coastal communities who use mangrove fruit as local products. Therefore, by holding a marine environment reclamation, mangrove ecosystems will be restored as well as the economy of the surrounding community.

Moreover, it also is to develop the tourism object performance. The sector to be developed after the construction of a flood retaining embankment is in the tourism sector with its infrastructure. This can be seen with the development and development of attractions in several places in the coastal populations including in the coastal area of the Kajen. Data from the Department of Tourism and Culture of Kajen in 2019 resulted in 12 locations in Kajen that have been and potentially become objects of tourist attraction in the coastal areas. Thus, the reclaimed land can be utilized as a business of the surrounding community for the welfare of their family life. Guidance and training for fisheries, trade, and tourism by the local government through related institutions in the community will increase the capacity and ability to develop into a coastal tourism area. As stipulated in Article 15 of the Law on Land Stewardship 2004, the management and use of coastal reclamation land in coastal areas is permissible as long as it takes into account the limited carrying capacity, sustainable development, linkages of ecosystems, biodiversity, and the preservation of environmental functions.

Because the enactment of the Coastal and Small Islands Management Act of 2014 reduced the authority of the Provincial Government to authorize and supervise marine and coastal environment, the development of a new policy is needed and should be beneficial for all parties, not only to satisfy the government as a policymaker, but the policy is beneficial to the public at large. The implementation of the coastal reclamation policy must pay attention to the damage to the land, marine ecosystems, and the environment around the coast so that the negative impact of the marine environment reclamation policy can be minimized and not suffer damage to the land around the coast/coast, marine ecosystems, and the environment. This certainly requires supervision from the local government in collaboration with coastal communities.

\section{CONCLUSION}

The economic and environmental issues become the main consideration for coastal reclamation land in Kajen, Central Java. This is to develop coastal community businesses and improve the welfare of fishermen and to develop conservation of natural resources such as mangroves and fish ponds and developing tourist areas for the welfare of surrounding communities. Management and utilization of land reclaimed by the coast in coastal areas are permitted by law, as long as it takes into account the limited carrying capacity, sustainable development, linkages of ecosystems, biodiversity, and preservation of environmental functions. This is as stipulated in Article 15 of Law Number 16 of 2004 concerning Land Stewardship.

Equitable coastal reclamation policy is carried out by reconstructing the value of policies in the form of partitioning and humanistic policies by genuinely involving the community and reconstructing policy laws, including the application of the 2014 Local Government Law and the Minister of Maritime Affairs and Fisheries Regulation No. 23 of 2016 also the Law on the Management of Coastal Areas and Small Islands in 2007 and Presidential Regulation No.122 of 2012 must be consistent and comprehensive in the field for legal certainty in the management of coastal areas and small islands. Conflicts of authority must be revoked immediately by revising changes to the article. The Marine environment Reclamation Policy from Law to Regional Regulations must be oriented towards substantive justice with a progressive legal basis based on the Pancasila and the 1945 Constitution. The policy governs criminal sanctions and fines for law enforcers who violate the laws and regulations, not only administrative sanctions for legal protection and legal certainty and the existence of clear rules regarding the sea and coastal supervision by the local area in cooperation with relevant agencies in the regions, provinces and central government levels.

The findings suggest for local governments to optimize coastal reclamation as a tourist area that supports the concept of the reclaimed marine environment area for tourist attractions. It is hoped that cooperation and partnerships between the government, the private sector, and the community in the management of the area by all relevant parties, so that the development and maintenance of the reclaimed land can be awake and sustainable. For the central government, there is a need for immediate response to 
policy revision on laws and regulations relating to conflicting marine environment reclamation authority. The development of a new accommodative policy is needed to ensure legal certainty and legal protection for coastal communities.

\section{REFERENCES}

Alwasilah, C. (2002). Qualitative Subject: Basic Fundamentals of Designing and Conducting Qualitative Research. Jakarta: Pustaka Jaya.

Arsyad, A. (2008). Coastal reclamation projects in Indonesia: the weaknesses which lead to severe socio-environmental impacts. In Proceedings International Conference on Environmental Research and Technology. Universiti Sains Malaysia (pp. 426-429).

Azhar, M., Solechan, S., Saraswati, R., (...), Suhartoyo, S., \& Ispriyarso, B. (2018). The New Renewable Energy Consumption Policy of Rare Earth Metals to Build Indonesia's National Energy Security. E3S Web of Conferences 68,03008 https://doi.org/10.1051/e3sconf/20186803008

Azwar, S. A., Suganda, E., Tjiptoherijanto, P., \& Rahmayanti, H. (2013). Model of sustainable urban infrastructure at coastal reclamation of North Jakarta. Procedia Environmental Sciences, 17, 452-461. https://doi.org/10.1016/j.proenv.2013.02.059

Bäckstrand, K. (2003). Civic science for sustainability: reframing the role of experts, policy-makers and citizens in environmental governance. Global Environmental Politics, 3(4), 24-41. https://doi.org/10.1162/152638003322757916

Colchester, M., Jiwan, N., Andiko, M. S., Firdaus, A. Y., Surambo, A., \& Pane, H. (2007). Promised land: palm oil and land acquisition in Indonesia: implications for local communities and indigenous peoples. Bogor, Indonesia: Perkumpulan Sawit Watch.

Contreras-Hermosilla, A., Fay, C., \& Effendi, E. (2005). Strengthening forest management in Indonesia through land tenure reform: issues and framework for action. Nairobi: World Agroforestry Centres

Dewi, G. S. (2019). Penolakan masyarakat terhadap reklamasi teluk benoa provinsi bali. Diponegoro Private Law Review, 4(1).

Djainal, H. (2020). Reklamasi pantai dan pengaruhnya terhadap lingkungan fisik di wilayah kepesisiran Kota Ternate. Jurnal Lingkungan Sultan Agung, 1(1), 16-28.

Dutton, I. M. (2005). If only fish could vote: The enduring challenges of coastal and marine resources management in postReformasi Indonesia. The politics and economics of Indonesia's Natural Resources, 162-178. https://doi.org/10.1355/9789812305497-016

Firman, T. (1997). Land conversion and urban development in the northern region of West Java, Indonesia. Urban Studies, 34(7), 1027-1046. https://doi.org/10.1080/0042098975718

Firman, T. (2004). Major issues in Indonesia's urban land development. Land Use Policy, 21(4), 347-355. https://doi.org/10.1016/j.landusepol.2003.04.002

Flaherty, M., \& Karnjanakesorn, C. (1995). Marine shrimp aquaculture and natural resource degradation in Thailand. Environmental Management, 19(1), 27-37. https://doi.org/10.1007/BF02472001

Fortes, M. D. (1991). Seagrass-mangrove ecosystems management: a key to marine coastal conservation in the ASEAN region. Marine Pollution Bulletin, 23, 113-116. https://doi.org/10.1016/0025-326X(91)90659-G
Gangga Santi Dewi, I.G.A. (2019). Legal review of positive impact of beach reclamation in pekalongan city. International Journal of Scientific and Technology Research 8(11), 1289-1292

Harsono, B. (2002). Indonesian Agrarian Law. Jakarta: Djambatan

Huda, M. C. (2013). Pengaturan Perizinan Reklamasi Pantai Terhadap Perlindungan Lingkungan Hidup. Perspektif, 18(2), 126-135.

https://doi.org/10.30742/perspektif.v18i2.121

Jusoff, K. (2013). Malaysian Mangrove Forests and their Significance to the Coastal Marine Environment. Polish journal of environmental studies, 22(4).

Kalalo, F. P. (2019). Stakeholder Perception and Awareness on the Causal Relationship between Mining Exploitation and Environmental Degradation in Minahasa Region Indonesia. International Journal of Energy Economics and Policy, 9(4), 327. https://doi.org/10.32479/ijeep.7689

Kusen, J. D., \& Tioho, H. (2009). The present status of coral reef condition in Bunaken National Park and Manado Bay, North Sulawesi, Indonesia. Galaxea, Journal of Coral Reef Studies, 11(2), 219-222. https://doi.org/10.3755/galaxea.11.219

Mahfud, M.D. (2010). Debate on Constitutional Law Post Constitutional Amendment. Jakarta: Rajawali Pers.

Marfai, M. A., \& King, L. (2008). Coastal flood management in Semarang, Indonesia. Environmental geology, 55(7), 1507-1518. https://doi.org/10.1007/s00254-007-1101-3

Marfai, M. A., Almohammad, H., Dey, S., Susanto, B., \& King, L. (2008). Coastal dynamic and shoreline mapping: multisources spatial data analysis in Semarang Indonesia. Environmental monitoring and assessment, 142(1-3), 297308. https://doi.org/10.1007/s10661-007-9929-2

McCarthy, J., \& Zen, Z. (2010). Regulating the oil palm boom: Assessing the effectiveness of environmental governance approaches to agro-industrial pollution in Indonesia. Law \& Policy, 32(1), 153-179. https://doi.org/10.1111/j.1467-9930.2009.00312.x

Muhardjir, N. (2002). Qualitative Research Methodology.Yogyakarta: Rake Sarasin.

National Legal Development Agency of the Ministry of Law and Human Rights of the Republic of Indonesia. (2015). Final report on legal review of the division of central and regional authorities in marine management research and development center for the national legal system. Jakarta: National Legal Development Agency of the Ministry of Law and Human Rights of the Republic of Indonesia

Priyandes, A., \& Majid, M. R. (2009). Impact of Reclamation Activities on the Environment Study Area: Northern Coast of Batam, Indonesia. Jurnal Alam Bina, 10(1), 1-11.

Rahardjo, S. (2009). Layers in Legal Studies. Bandung: Alumni.

Rasiah, R., Guptan, V., \& Habibullah, M.S. (2018). Evaluating the impact of financial and economic factors on environmental degradation: A panel estimation study of selected Asean countries. International Journal of Energy Economics and Policy 8(6), 209-216

Retnowati, E. (2011). Nelayan indonesia dalam pusaran kemiskinan struktural (perspektif sosial, ekonomi dan hukum). Perspektif, 16(3), 149-159. https://doi.org/10.30742/perspektif.v16i3.79

Soeratno, S., \& Lincoln, A. (1993). Research Methodology for Economics and Business. Yogyakarta: APMP YKPN

Tamanaha, B. Z., A. (2006). General Jurisprudence of Law and Society. New York: Oxford Unity Press.

Tunas, D., \& Peresthu, A. (2010). The self-help housing in Indonesia: The only option for the poor?. Habitat International, 34(3), 315-322. https://doi.org/10.1016/j.habitatint.2009.11.007 
Tungka, A. E., Omran, A. A., Gebril, A. O., Wah, W. S., \& Suprapti, A. B. (2012). Manado Waterfront Development Concept As Sustainable City Of Tourism. Acta Technica CorviniensisBulletin of Engineering, 5(2), 31.

Walyoto, S., \& Peranginangin, J. (2018). Economic analysis of environmental and cultural impacts of the development of palm oil plantation. International Journal of Energy Economics and Policy 8(5), 212-222

Wells, M. P., \& McShane, T. O. (2004). Integrating protected area management with local needs and aspirations. AMBIO: a Journal of the Human Environment, 33(8), 513-519. https://doi.org/10.1579/0044-7447-33.8.513

Wisha, U. J., Al Tanto, T., Pranowo, W. S., \& Husrin, S. (2018). Current movement in Benoa Bay water, Bali, Indonesia: Pattern of tidal current changes simulated for the condition before, during, and after reclamation. Regional Studies in Marine Science, 18, 177-187. https://doi.org/10.1016/j.rsma.2017.10.006
Wong, P. P. (1998). Coastal tourism development in Southeast Asia: relevance and lessons for coastal zone management. Ocean \& Coastal Management, 38(2), 89-109. https://doi.org/10.1016/S0964-5691(97)00066-5

Yurnita, A., Trisutomo, S., \& Ali, M. (2017, July). Assessing the sustainable development of coastal reclamation: a case of Makassar using GIS application. In IOP Conference Series: Earth and Environmental Science (Vol. 79, No. 1, p. 012013). IOP Publishing. https://doi.org/10.1088/1755-1315/79/1/012013

Zamroni, Z. (1992). Advanced Introduction to Social Theory. Yogyakarta: Tiara Yogya.

Zerner, C. (1994). Through a green lens: The construction of customary environmental law and community in Indonesia's Maluku Islands. Law and society review, 1079-1122. https://doi.org/10.2307/3054024

Received on 16-01-2021

https://doi.org/10.6000/1929-4409.2021.10.82

(C) 2021 Turisno and Dewi; Licensee Lifescience Global.

This is an open access article licensed under the terms of the Creative Commons Attribution Non-Commercial License (http://creativecommons.org/licenses/by-nc/3.0/) which permits unrestricted, non-commercial use, distribution and reproduction in any medium, provided the work is properly cited. 